\title{
Teacher Competency on Learner Promotion in Embu County Integrated Public Primary Schools, Kenya
}

\author{
Kamwitha A. Muthanje $\mathrm{e}^{1, *}$, Khatete I. Wafula ${ }^{1} \&$ Riechi, A. Rasugu ${ }^{2}$ \\ ${ }^{1}$ Faculty of Education; Department of Educational Administration and Planning, University of Nairobi, Kenya \\ ${ }^{2}$ School of Education, Koitaleel Samoei University College \& Department of Educational Administration \& Planning, \\ University of Nairobi, Kenya \\ *Correspondence: Faculty of Education; Department of Educational Administration and Planning, University of \\ Nairobi, Kenya. E-mail: ib2khatete6@gmail.com
}

Received: May 29, 2020

Accepted: June 10, 2020 Online Published: June 20, 2020

doi:10.5430/wje.v10n3p188

URL: https://doi.org/10.5430/wje.v10n3p188

\begin{abstract}
Investing in ECDE is one of the challenging cost-effective commitments that a government can undertake. Investing in quality ECDE can improve a child's well-being and minimize educational and poverty gap. Teacher competence is an important tool towards the realization of holistic development of children. It is with this background that the researcher sought to study teacher competence on Learners' promotion in Embu County integrated public primary schools, Kenya. The study adopted cross-sectional survey research design across a target population of 381 public primary schools, 381 head teachers, 3951 primary teachers and 380 ECD teachers in the five sub-counties. Stratified random sampling was used to select schools from the five sub-counties; simple random sampling was used to select public primary teachers and head teachers in five sub- counties. Questionnaires were utilized as the instruments of the study. Quantitative data collected was analyzed using SPSS software. Based on the results, the study found that most $(73 \%)$ of the primary teachers are unable to handle ECD pupils transiting to primary section since they could not understand the content taught and teachers have inadequate experience for teaching ECDE class. The study also found that most $(50 \%)$ of the head teachers do not avail curriculum support materials. The study recommends that the teacher training colleges should incorporate courses that equip teachers with skills to handle pupils transiting from ECD classes to primary section. The schools also should provide books to a pupil book ratio of 1:1 so as to execute the new competent based curriculum.
\end{abstract}

Keywords: teacher competence, early childhood development education, curriculum materials, promotion

\section{Introduction}

\subsection{Background of the Problem}

Teachers are considered as a major determinant and most important input to basic education of student achievement (Education for All (EFA) (Philippines), 2015). According to Adu (2012), the level of a teacher's subject matter competence is a prime predictor of pupils' learning. Thus, it is not only the qualifications obtained by a teacher that could contribute to a teacher's quality but actual achievement in terms of subject matter competencies. Therefore, researchers attribute the low achievement of pupils in schools to teachers' inadequacy in understanding the subject matter.

According to Mbilinyi (2003), teacher's background, such as academic qualifications and teaching experience is related to the student achievement. Therefore, teachers have a very big role to play in the teaching and learning process, and also the chief facilitators for learning to take place. Thus, the two main factors about teachers that seriously affect school performance are adequacy and quality hence the inadequacy of teachers in a school causes idleness, boredom in the learners and wastage of time which consequently lead to low internal efficiency.

Extensive in-service training programme with a regular two-year course and a new five-week short course were offered by the World Bank. This resulted in the PTR decline which greatly contributed to quality of ECD Centres. Despite of this result, the ECD teachers felt that the short courses offered was insufficient to equip them with the 
necessary knowledge and skills. Consequently, National Centre for Early Childhood and Education (NACECE) staff felt that the short courses offered were inadequate since irregular workshops were being organized by District Education Centre for Early Childhood Education (DICECE) due to lack of boarding facilities. Thus, the government of Kenya through the Draft Sessional Paper No.1 of 2005 took care of this through Constituency Development Fund (CDF) though this was at a small margin (UNESCO, 2005).

According to Lockheed and Verspoor (1991), the cost of initial training can be reduced by using shorter initial training periods and greater use of teacher in-service sessions. To focus on initial training may be cost-effective because of organizational and physical realities that may prelude mounting expensive in-service training sessions for teachers. Thus, the government of Kenya provide in-service Early Childhood Development (ECD) training to primary school teachers so as to meet the issues related to unprepared of early grade pupils. This help primary school teachers improve in handling pupils in early grades for greater efficiency though the number of teachers upgrading has to be improved (UNESCO, 2005). Ayiro (2016) highlighted the four factors suffocating our education system in Kenya as; teachers are central in education sector as they determine what students achieve; teachers to apply all skills and strategies of effective teaching; teachers must be exposed to continuous professional development through in-service training beside proper remuneration and finally that the infrastructure and instructional material provided under Free Primary Education (FPE) are grossly inadequate for use by the teachers who are not full competence in specific subjects. Thus, children who enter school with lower levels of literacy, numeracy and learning development need have access to well- trained and experienced teachers. This provides a foundation for smooth progression through the system (UNESCO, 2011).

According to Annual Report of the Ministry of Education, Science and ICT year 2013-2014 of Embu County, majority of the schools had at least 50 teachers who were needed to lower the pupil teacher ratio in in Embu County public primary schools which was 32: 1 . This was quite high ratio which undermined learning particularly in lower primary and in ECD classes. A number of ECD teachers had certificates which had no official ministry of education seal. Also two teachers who were already teaching had referrals in Kenya National Examination Centre for Early Childhood Development Education (KNECECDE). This was an indication of low qualification and that the children they were teaching were unlikely to have smooth progression to the primary section. It is in this early part of the development for the young ones that forms the basis for strong foundations in primary school level and if not taken care of can lead to total failure of children in their basic education. This occurs especially when confronted by among many challenges low qualification of teachers who find it difficult to handle ECD transiting children to primary section hence the necessity of embarking on the study of teacher competence on learners' promotion in Embu County integrated public primary schools, Kenya. The main objectives of the study were to: establish adequacy of teachers to handle ECD classes; establish reasons for inadequacy of teachers to handle pupils transiting from ECD classes; assess adequacy of teaching and learning materials to attract pupils transiting to class 1 and establish reasons why curriculum materials are not useful.

\subsection{Related Literature}

Teacher professional qualification has been linked to overall classroom quality. Primary school teacher with early childhood training are more effective in early grades since they are more equipped with information on how young children learn and develop. This helps them ease transition of children in schools much more than teachers who lack this background. Teachers with early childhood training are more likely to use developmentally appropriate practices in the classroom. Investment in primary teacher education with an emphasis on early childhood pays great dividends for educational efficiency and student learning (Britto, 2012). Teachers with early childhood training are more likely to use developmentally appropriate practices in the classroom. Primary teacher's education with an emphasis on early childhood pays great dividends for educational efficiency and student learning (UNICEF, 2012).

According to Kelleher (2011), preparing pre-primary teachers is one of the biggest school-related factors that increase quality in both classroom process and relationships. Teacher professional qualifications influence the quality of classroom interaction (Rao, 2010). The poorly prepared teachers struggle to use the kind of curricular adopted (Kelleher, 2011). Young children are often assigned the least effective teachers due to the low status attached to this schooling level (O' Gara, 2013). The untrained and unqualified staffs are often employed, and the low status and pay are linked to high turnover hence damaging learning outcomes (Mathers et al., 2014).

Traditionally, the care of young children is seen as women's work in many countries. This translates to lower pay and less professionalization and respect (Kelleher, 2011). San et al (2015) stated that it is a challenge to get trained ECCE teachers to work in poor rural and difficult-to-reach communities. These are the areas where low participation is normally high and this translates into low transition rates to primary schools. Chikwiri \& Musiyiwa, (2017) in their 
journal article on Challenges and gaps in children's transition from early childhood development to grade one in Zimbabwe noted that lack of appropriately qualified ECD teachers affected transition of learners from ECD to grade one. The government of Zimbabwe committed itself to train ECD teachers at primary teachers colleges so as to fill the gap.

According to Oke (2016) when a child's first teacher is poorly trained, the foundation of learning will be poor. Teacher qualification is important for the learners to learn effectively and transit to the next grade. If the school goals and objectives have to be met, teachers must be well trained. This is because when teachers are not given on the job training or orientation on the same from time to time, their knowledge on provision of the learning environment, adequate learning facilities, and adequate instructional materials become outdated. According to Afoma \& Omotuyole, (2013) when instructional materials are not well utilized due to ignorance of the teachers, efficiency of education slows communicative competence of the learners. This eventually leads to absenteeism and consequently dropout hence wastage in education is experienced.

According to Afoma \& Omotuyole (2013) inadequate teacher qualification poses problems in the usage of locally made instructional materials which makes children not have effective learning. ECD teachers to be retrained on the utilization of locally made learning materials for the effective teaching and learning for successful transition from one class to another. Quality of education depends extensively on quality of the teacher. Thus, teachers need to be highly qualified in the application of pedagogical skills so as to make learning effective (Kafyulilo, Rugambuka \& Moses, 2012).

According to Makunja, (2016), inadequate in-service teacher training was a great challenges affecting satisfactory implementation of the curriculum. The teachers' preparedness and readiness in the use and application of informative knowledge during instruction and learning process was inadequate. Teachers lack training in ICT skills to enable them introduce the Competency Based Curriculum in the schools (Bingimlas, 2009). Teachers lack adequate knowledge and skills in the usage of integrate technology which support curriculum implementation (Bonnano, 2011). According to Kinuthia (2009), majority of teachers in Kenya are computer illiterate and only a few can competently use computer in imparting knowledge and skills in a classroom situation.

Administrative who works for effective/quality teaching and caters for more teacher training will have higher retention capacity in the school than one who concentrates more on expanding physical facilities where teachers in their personality traits do not display emotional stability, extraversion and dependability and pupils' performance will be affected (Akengo, 2007). The district Teachers Service Commission should establish and implement a transparent, explicit rule on the deployment of teachers across the schools within the districts and establish procedures to regularly monitor deployment. Also, multi-grade teaching, distant learning and construction of teacher in-service training colleges were to be put in place (Winkler et al., 2008)

\subsection{Theory}

The study is based on the Education Production Function Theory as advanced by Hanushek (2008). In this production function theory; education process is looked at as where inputs are converted to outputs. Thus, inputs such as teachers and instructional materials among many others are important to student achievement in an educational process. Thus, the function shows relationship between two or more variables. These variables can be teacher adequacy and adequacy of teaching and learning instructional materials which are some of the factors contributing to low levels of promotion hence low internal efficiency in ECD and in primary schools. In equation form production function can be represented by: -

$\mathrm{A}=\mathrm{f}(\mathrm{C}, \mathrm{D}$ and many others), where

$\mathrm{A}=$ Achievements in terms of promotion rates

$\mathrm{C}=$ Teacher adequacy

$\mathrm{D}=$ Adequacy of teaching and learning instructional materials

The theory therefore is related to those aspects of education production activity that can be measured for example promotion of learners. The input will be determined in form of adequacy of teachers and adequacy of teaching and learning instructional materials to attract pupils transiting to class. The output will be determined in form of pupils' promotion to the next grade. The aim is to establish if the existing inputs will be used to produce maximum output in this study of teacher competence on learner promotion in Embu County integrated public primary schools, Kenya. 


\section{Methods and Materials}

\subsection{Study Design}

The study adopted descriptive survey design to assess the teacher competence on learner promotion in Embu County integrated public primary schools, Kenya. Orodho (2002) noted that in descriptive survey, information is collected by interviewing or administering of questionnaires to a sample of individuals. This research employed descriptive survey design, which enabled the provision of insight into intensive, descriptive and holistic analysis of a single entity. This increased the reliability of the research findings which was generalized to the entire population. Survey research was used since it quantified information that was used for statistical inference on target population through the data analysis. It was also helpful in survey of demographic traits in certain group like the age, gender, academic level, professional qualification and work experience among others.

\subsection{Participant (Subject) Characteristics}

The study targeted the head teachers, primary teachers and ECD teachers in 381 public primary schools and 380 ECD schools from Mbeere North, Mbeere South, Embu East, Embu West and Embu North sub-counties of Embu County, Kenya.

\subsection{Sampling Procedures}

The study used the sample size taken from the five Sub Counties for study from 381 public primary schools in Embu County. Ten percent of the total population of primary and pre-schools was considered for the study which is recommended by research scholars such as Gay (2000). Stratified random sampling procedure was used to select schools for the study from the five sub counties as shown in table 1 .

Table 1. Target Population of Primary and ECDE Schools in Embu County, Kenya

\begin{tabular}{llllll}
\hline Sub county & Schools & Head teachers & Primary Teachers & $\begin{array}{l}\text { No. of ECDE } \\
\text { Schools }\end{array}$ & $\begin{array}{l}\text { ECDE } \\
\text { teachers }\end{array}$ \\
\hline Mbeere North & 96 & 96 & 446 & 96 & 129 \\
Embu West & 37 & 37 & 507 & 35 & 53 \\
Embu East & 71 & 71 & 778 & 68 & 75 \\
Mbeere South & 140 & 140 & 1300 & 145 & 176 \\
Embu North & 37 & 37 & 446 & 36 & 50 \\
Total & $\mathbf{3 8 1}$ & $\mathbf{3 8 1}$ & $\mathbf{3 9 5 1}$ & $\mathbf{3 8 0}$ & $\mathbf{4 8 3}$ \\
\hline
\end{tabular}

Source: Pupils and Teachers returns as at $15^{\text {th }}$ March 2016 in TSC Director's Office, Embu.

The study used the sample size taken from these Sub Counties for study from 381 public primary schools with 380 ECDE schools. Ten percent of the schools from each sub county was considered for the study. This is shown in table 2.

Table 2. Sample Size

\begin{tabular}{lllll}
\hline Sub-districts in Embu & Primary & Sample & Pre-schools & Sample \\
\hline Mbeere North & 96 & 10 & 96 & 10 \\
Embu West & 37 & 4 & 35 & 4 \\
Embu East & 71 & 7 & 69 & 7 \\
Mbeere South & 140 & 14 & 143 & 14 \\
Embu North & 37 & 4 & 36 & 4 \\
\hline
\end{tabular}

Purposive random sampling procedure was used to arrive at the sample of primary school teachers and head teachers. Thus, 39 head teachers were selected from each sampled primary schools. Two primary teachers were selected too from each sampled schools. One primary teacher from upper and one from lower primary school were selected for the study. ECDE teachers too were purposively selected from each sampled ECDE schools. Those who participated in the study were a total of forty two (42) ECDE teachers. Thus, a total of 39 head teachers, 76 primary teachers and 42 ECD teachers were used for the study. 


\subsection{Instruments and Procedures}

This study used questionnaires for the head teachers, primary school teachers and pre-school teachers to get information on teacher competence on promotion of learners in Embu County integrated public primary schools, Kenya. Mugenda \& Mugenda (2003), assert that a questionnaire is a written set of questions to which the subjects respond in writing. The study used unstructured open-ended, structured closed ended, partly contingency (closed and open-ended) and the matrix questions. The questionnaires were administered to 42 ECD teachers, 49 head teachers and 76 upper and lower primary teachers to fill in. The filled up questionnaires were collected after two weeks. Questionnaires were used because they are convenient to administer to literate respondents and for collecting information within a short span of time.

\subsection{Validity of the Instruments}

Validity is the accuracy and meaningfulness of inferences, which are based on the research results. Thus, validity is the degree to which results obtained from the analysis of the data actually represents the phenomena under study. Content validity is a measure of the degree to which data collected using a particular instrument represents a specific domain of indicators or content of a particular concept (Mugenda \& Mugenda, 2003). Borg \& Gall (1989) define validity as the degree to which a test measures what it purports to measure.

To establish validity of the instrument in this study, the researcher prepared the questionnaires to solicit information of teacher competence on promotion of learners in integrated Embu County public primary schools, Kenya in close consultation with the supervisors in order to ensure that the items in the questionnaire covered all the areas under study. Best \& Kahn (2002) observed that, content validity of the research instruments could be enhanced through expert judgment. The researcher's supervisors, as experts, helped to assess the validity of the instruments.

\subsection{Reliability of the Instruments}

Reliability, according to Orodho (2005), refers to the degree to which a particular measuring procedure gives similar results over a number of repeated trials. According to Mugenda \& Mugenda (2003), test-retest reliability of data involves administering the same instrument twice to the same group of subjects. The researcher gave questionnaires to the pilot respondents to fill in, and then after a week, the researcher gave the same questionnaire to the same respondents again. (Mugenda \& Mugenda, 2003) asserts that instruments and the data are said to be reliable, if there is a high co-efficient of reliability or stability from the test re-test technique. The researcher used Spearman's formula to compute the correlation co-efficient of the instruments. The result yielded a correlation co-efficient of 0.91, which is considered appropriate as recommended by Orodho (2009), Kombo \& Tromp (2006) who argued that a correlation coefficient of 0.7 is considered good.

\subsection{Data Analysis Procedure}

Qualitative and quantitative information was analyzed using the Statistical Package for Social Sciences (SPSS) version 19 to increase accuracy of results so as to bring order structure and interpretation to the mass of collected data (Sarantakos, 2013). In regard to quantitative data, after the researcher administered questionnaires, the mass of raw data collected was quantitatively analyzed whereby close-ended and open-ended responses were assigned codes. Responses were placed into given categories. The researcher converted collected data into numerical codes representing attributes of variables to permit quantitative analysis. The researcher used one code to assign each response category (Sarantakos, 2013). The researcher further used Frequency tables.

As recommended by (Mertens, 2010), the researcher coded the collected data and gave themes: teachers responses on whether they feel adequate to handle ECD classes, reasons for lower primary teachers feeling inadequate to handle pupils transiting from ECD classes, teachers responses on adequacy of teaching and learning materials to attract pupils from ECD to class one, reasons for curriculum materials not being useful in Embu County integrated public primary schools. The researcher further described and summarized data using descriptive statistics so as to meaningfully describe a distribution of scores using statistics. The researcher also used Frequencies and percentages in table form. The researcher summarized the written information in form of a report with application to implication of findings and recommendations. 


\section{Results}

\subsection{Teachers Adequacy to Handle ECD Classes}

Concerning handling of ECD classes, the teachers were asked to indicate whether they feel adequate. Their responses as either Yes or No are as presented in Table 3.

Table 3. Adequacy of Teachers to Handle ECD Classes

\begin{tabular}{lll}
\hline & Frequency & Percent \\
\hline Yes & 22 & 26.8 \\
No & 60 & 73.2 \\
Total & 82 & 100.0 \\
\hline
\end{tabular}

Table 3 Shows that the majority of the teachers of lower primary classes $73 \%$, said that they feel unprepared to teach transiting ECD classes. $26.8 \%$ of the respondents indicated that they feel prepared to handle the transiting ECD class.

3.2 Reasons for Lower Primary Teachers Feeling Inadequate to Handle Pupils Transiting from ECD Class

Those who indicated that they feel inadequately prepared were asked to indicate the reasons for the same. Their responses are as presented in Table 4

Table 4. Reasons Why Lower Primary Teachers Feel Inadequate to Handle Transiting ECD Class

\begin{tabular}{lll}
\hline & Frequency & Percent \\
\hline No adequate experience for not having taught ECD class & 9 & 25.7 \\
Most of pupils do not understand the content being taught & 14 & 40.0 \\
I have not done ECDE course (Diploma) & 1 & 2.9 \\
They are not well prepared for class 1 & 2 & 5.7 \\
No teaching and learning materials & 7 & 20.0 \\
No ICT curriculum & 2 & 5.7 \\
Total & 35 & 100 \\
\hline
\end{tabular}

Table 4 shows that most of the teachers $40 \%$ indicated that they are unable to handle ECD pupils transiting to primary section because most of the pupils are not able to understand the content taught while another $25.7 \%$ indicated that they feel inadequate to handle transiting ECD class for lack of adequate experience of teaching ECD class. Another $20.0 \%$ stated that they feel inadequate to handle pupils transiting from ECD for not having teaching and learning materials while had no teaching and learning materials while $5.7 \%$ acknowledged there is no ICT curriculum for pupils transiting from ECD classes and also teachers feel not well prepare for class 1 from the transiting ECD class. $2.9 \%$ have not done ECD diploma to enable them handle the pupils transiting to primary section.

\subsection{Teachers' Responses on Adequacy of Teaching and Learning Materials to Attract Pupils from ECD to Class One}

Further, the primary school teachers were also asked to indicate whether teaching and learning materials in class one are adequate to accommodate pupils graduating from ECD. This is as presented in Figure 1. 


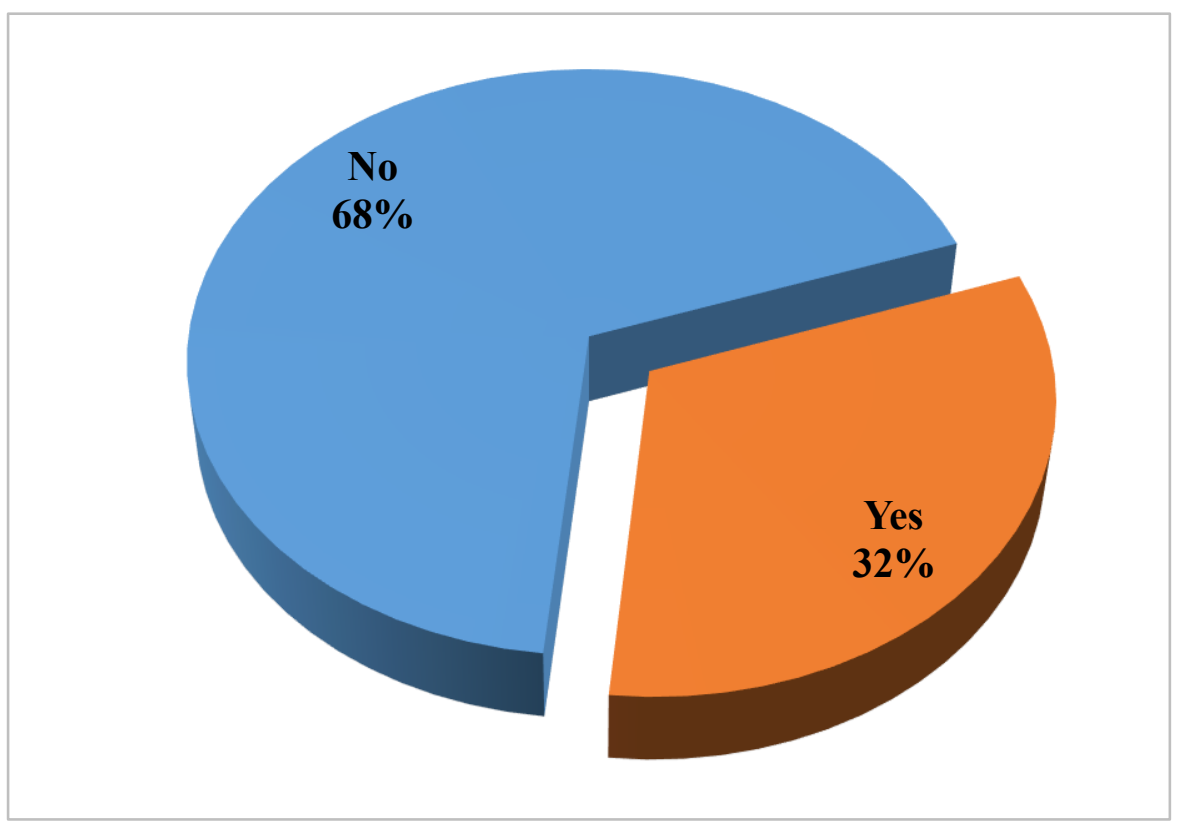

Figure 1. Teachers' Responses on Adequacy of Teaching and Learning Materials to Attract Pupils from ECD to Class One

Figure 1 shows that most (68\%) of the primary school teachers said that teaching and learning materials in class one is not adequate enough to accommodate pupils from ECD classes while $32 \%$ that teaching and learning materials are adequate enough to attract pupils from ECD to class one.

\subsection{Head Teachers Being Conversant with ECD Curriculum Materials}

On the level of head teachers' acquaintance with curriculum materials, the head teachers were asked to indicate whether they were conversant with them or not. This is as reported in Figure 2.

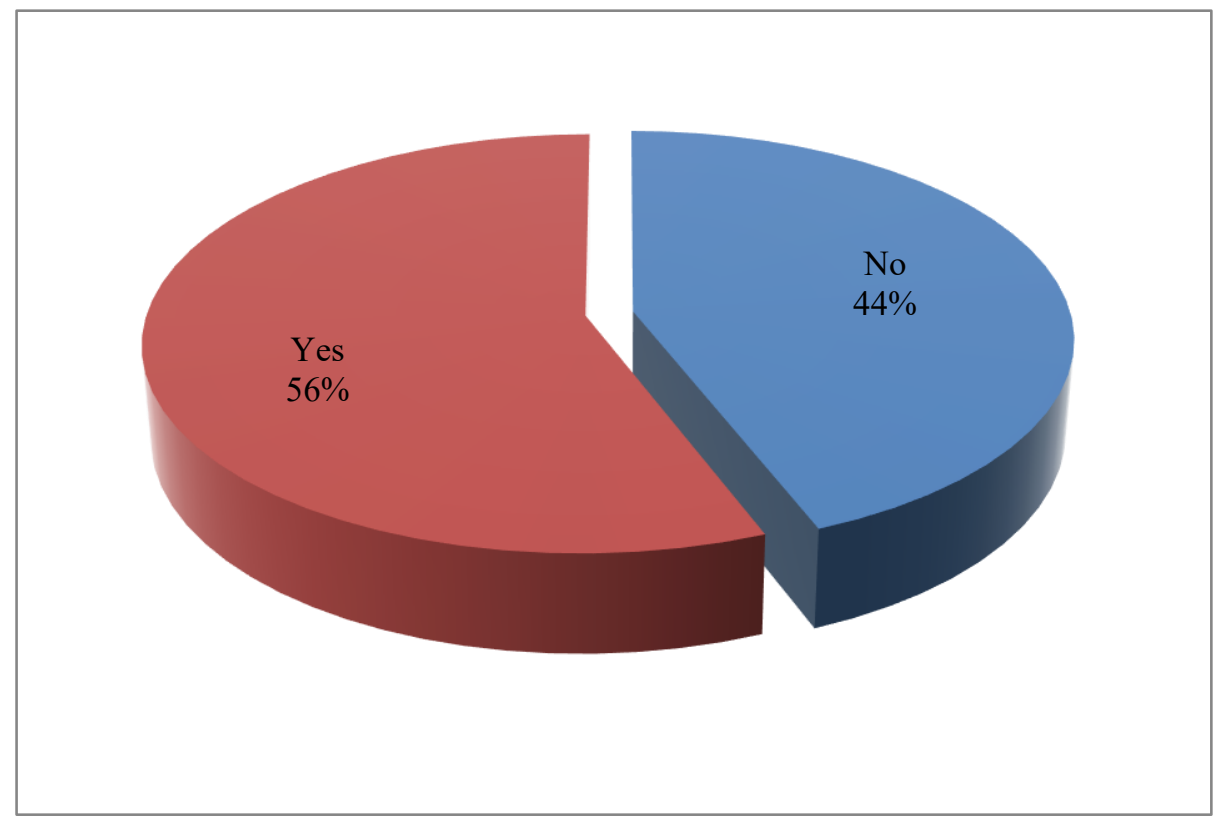

Figure 2. Head Teachers Being Conversant with ECD Curriculum Materials 
The results in Figure 2, shows that most of the head teachers 56 percent are conversant with ECD curriculum as given by the Kenya Institute of Curriculum Development but are not able to deliver competency based curriculum.

\subsection{Causes of Inadequate Curriculum Materials}

The head teachers were asked to establish the causes of inadequate curriculum materials. The results are as presented in Table 3.

Table 5. Causes of Inadequate Curriculum Materials

\begin{tabular}{lll}
\hline & Frequency & Percent \\
\hline Consultations with teachers and stakeholders. & 3 & 50.0 \\
Parents provides & 1 & 16.7 \\
There is a TUSOME programme & 1 & 16.7 \\
Liaising with county government for support & 1 & 16.7 \\
Total & 6 & 100.0 \\
\hline
\end{tabular}

Table 5 Indicate that most (50\%) of the head teachers indicated that they did not avail curriculum support material to schools because teachers improvised. The rest $16.7 \%$ of the head teachers said that the school does not provide curriculum support materials since parents provided them. Another group of head teachers indicated that the TUSOME programme in schools provided curriculum support materials and therefore school needed not to provide. Others indicated that they liaised with the county government for the provision of such instructional materials.

\section{Summary and Discussion}

Most (73\%) of the teachers are not able to handle pupils transiting from ECD to primary section. $40 \%$ of the teachers attributed this to pupils not being able to understand the content taught and $25.7 \%$ of the teachers attributed this to inadequate experience for teaching ECD class. $20.0 \%$ of the teachers stated that they feel inadequate to handle pupils transiting from ECD for not having teaching and learning materials. Another 5.7\% acknowledged there is no ICT curriculum for pupils transiting from ECD classes and $2.9 \%$ said that they have not done ECD diploma to enable them handle the pupils transiting to primary section. This finding conquers with the suggestion given by Akman, Kent, Tarman \& Sanh, (2017) that preschool teachers and Grade one teachers were given opportunity to see both preschool class and Grade one during teaching /learning process so as to gain their skills in teaching. Further, the study echoed the finding of the study by Makunja (2016) which observed that there was inadequacy in in-service teacher training. This was a major drawback to effective implementation of the curriculum. The study perceived teachers' professional qualifications as a link to overall classroom quality. It further observed that primary school teachers with early childhood training were more effective when teaching in early grades since they were more equipped with competencies to be developed in young children during teaching and learning process. Also Britto (2012) noted that a well-equipped teacher with basic skills on handling young children in preschool with an emphasis on early childhood pays great dividends for educational efficiency and children education.

Most (68\%) of the primary school teachers said that teaching and learning materials in class one is not adequate enough to accommodate pupils from ECD classes.

Most (56\%) of the head teachers are conversant with ECD curriculum as given by the Kenya Institute of Curriculum Development but are not able to deliver competency based curriculum. This finding of the stud contradicts the findings of KNUT (2019) who observed that head teachers in Kenya were not given induction course on the supervisory and especially on Competence Based Curriculum.

Most (50\%) of the head teachers indicated that they did not avail curriculum support materials to schools because teachers improvised. The rest $16.7 \%$ said that the school does not provide them since parents provided. Another group indicated that the TUSOME programme in schools provided curriculum support materials and therefore school needed not to provide. Others indicated that they liaised with the county government for the provision of such instructional materials. The findings mimic the study by Bonnet, (2007) who asserted that in many developing countries the availability of adequate instructional materials is quite limited. Further, the study mirrored Republic of Kenya (2017), which indicated that the ECD center in Kenya relied on funds from the county government to buy instructional materials for schools. 


\section{Conclusion}

The teacher professional qualification indeed as established in the study demonstrates that transition of ECD class to primary section is greatly influenced by inadequate training of class one teacher on how to handle pupils transiting from ECD classes. Most of head teachers are not able to deliver competency based curriculum though they are conversant with ECD curriculum. Further the unavailability of instructional materials to teachers is highlighted from the findings as a factor contributing to transition of the pupils from ECD to primary school. The research reveals that majority of the teachers acknowledged inadequacy of teachers to handle pupils transiting from ECD to primary section. The study therefore recommends that teachers training colleges be equip teachers with skills to handle pupils transiting from ECD class. Also the study recommends that schools, parents and county government collaborate in provision of curriculum support materials. This would ensure seamless learning process when pupils transit to the next level of education with teachers who are able to handle pupils transiting from ECD to primary section.

\section{Acknowledgement}

I thank my supervisors Dr. Ibrahim Wafula Khatete and Dr. Andrew Rasugu Riechi who carefully read drafts of this study and made critical comments and important suggestions that kept me focused.

Am especially indebted to Embu County Director of Education and the heads of the five sub-county Directors of Education, namely Embu North, Embu West, Embu East, Mbeere North and Mbeere South for allowing me to collect data for my studies. I also thank all the primary head teachers, primary school teachers and Early Childhood Development and Education teachers for their availability and responses to all the questionnaires given to them and submitting them on time.

My special thanks to Sr. Sarah Tari, Sr. Josephine Muthoni, Sr. Teresa Njoki, Sr. Anne Tuki, Sr. Christine Wawira, Sr. Edna Sambu, Garissa SJT Community members, Embu SJT Community members, SJT Provincial Community members who were so instrumental in my studies. I thank in a very special way Rachel Maina who has always helped in editing this work in a very scholarly manner. Thanks to Sr. Emily Muthoni who really worked very hard by driving me to all sampled primary schools in Embu County while collecting my data. I also want to thank Sisters of Saint Joseph of Tarbes Embu community for allowing me to stay in their community during my data collection period. Special thanks to Mr. Kamwitha's family who kept on encouraging and praying for me even in moments when things were not easy in the course of this study.

\section{References}

Adeyemi, T. O., \& Adu, E. T. (2012). Teachers' Quality and Internal Efficiency in Primary Schools in Ekiti State, Nigeria. International Journal of Academic Research in Progressive Education and Development, 1(1), 188-212.

Afoma, R., \& Omotuyolle, C. (2013). Utilization of Locally Made Resources in Early Childhood Education to promote Effective Learning and Communicative Competence. Academic Journal of Interdisciplinary Studies, $2(8)$.

Akengo Arthur Nyawara. (2007). Factors that Influence Pupils' Dropout in Public Primary Schools in Asego Division, Homa Bay District (Unpublished M. Ed.). Project: Nairobi University of Nairobi. Accessed on Friday 19th December 2014.

Akman, B., Kent, K. S., Tarman, I., \& Sanh, S. Z. (2017). Examining Preschool and First Grade Teachers; Opinion on the Effects of School Readiness to Classroom Management. International Journal of Progressive Education, $13(1)$.

Ayiro. (2016, January 2). The Four Factors Suffocating Education System in Kenya. Saturday Nation, p. 32.

Best, J. W., \& Khan, J. V. (2002). Research in Education: Prentice Hall. New Delhi, India.

Bingimlas, K. A. (2009). Barriers to the Successful Integration of ICT in Teaching and Learning Environments: A Review of the Literature. Eurasia Journal of Mathematics, Science \& Technology Education, 5(3), $235-245$. https://doi.org/10.12973/ejmste/75275

Bonanno, P. (2011). Developing an Instrument to assess Teachers' Readiness for Technology Enhanced Learning. The $14^{\text {th }}$ International Conference on Integrative Computer Aided Learning. Slovakia Piet any, 21-23 September, pp. 438-443. https://doi.org/10.1109/ICL.2011.6059622 
Bonnet, G. (2007). What do recent evaluations tell us about the state of teachers in sub-Saharan countries? Background paper for EFA Global Monitoring Report 2008.

Borg, R. W., \& Gall, D. M. (1989). Educational Research: An Introduction. New York: Longman Inc.

Britto, P. R. (2012). School Readiness and Transitions: A Companion to the Child Friendly Schools Manual. Retrieved Wednesday March 30, 2016 from www.unicef.org. Early Childhood Development: The key to a full and productive life. Retrieved from http://www.unicef.org/dprk/ecd.pdf Education for All 2015 National Review Report: Kenya. Education in Developing Countries: Oxford University Press.

Chikwiri, E., \& Musiyiwa, J. (2017). Challenges and Gaps in Children's Transition from Early Childhood Development to Grade one in Zimbabwe. International Journal of Educational Administration and Policy studies, 9(7), 91-102. https://doi.org/10.5897/IJEAPS2017.0510

Education for All (Philippine). (2015). Implementation and Challenges (Phlippines-EFA-MDA-1 PDF). Accessed on 23/2/2016.

Gay, G. (2000). The Culturally Responsive Teaching. New York: Teachers College Press.

Hanushek E. A. (2008). Education Production Functions. The New Pulgrave Dictionary of Economics (pp.1-5). Pulgrave Macmillan UK: London. https://doi.org/10.1057/978-1-349-95121-5_1930-1

Kafyulilo, A. C., Rugambuka, I. B., \& Moses, I. (2016). The Implementation of Competence Based Training Approaches in Tanzania. The Case of Pre- Service Teacher at Morogoro Teacher Training College. Universal Journal of Education and General Studies, 1(11), 339-347.

Kelleher, F. (2011). Women and the Teaching Profession: Exploring the Feminization Debate. London/Paris Commonwealth Secretariat/UNESCO.

Kinuthia, W. (2009). Education Development in Kenya and the Role of ICT. International Journal of Education and Development using ICT, 5(2).

KNUT. (2019). Teachers Preparedness for the Implementation of the Competency-Based Curriculum in PrePrimary and Lower Primary Grades in Kenya. KNUT.

Kombo, D. K., \& Trop, A. L. (2006). Proposal and Thesis Writing: An Introduction. Publications Africa.

Lockheed, E. M., Verspoor, A. M., \& Associates. (1991). Improving Primary Education in Developing Countries. Oxford University Press.

Makunja, G. (2016). Challenges Facing Teachers in Implementing Competence-Based Curriculum in Tanzania: The Case of Community Secondary Schools in Morogoro Municipality. Educational Journal of Education and Social Science, 3(5).

Mbilinyi, D. S. (2003). Equity in Learning: The Gender Dimension. ADEA Biennial Meeting, Mauritius: Grand Baie.

Mertens, D. M. (2010). Research Evaluation in Education and Psychology. SAGE Publications.

Ministry of Education. (2013-2014). Baseline Survey of all the Early Childhood Units to establish their Status and Identify the Needs of the Institutions: Ministry of Education, Science, Technology and ICT. Embu County Government Annual Report.

Mugenda, O. M., \& Mugenda, A. G. (2003). Research Methods; Qualitative and Quantitative Approaches. Nairobi: Acts Press.

Oke, B. E. (2016). Influence of Early Childhood Instructional Supervision on Caregivers' Effectiveness in Federal Capital Territory Centers, Abuja Nigeria. International Journal for Cross-Disciplinary Subjects in Education (IJCDSE), 7(1). https://doi.org/10.20533/ijcdse.2042.6364.2016.0365

Orodho, A. J. (2005). Techniques of Writing Research Proposal and Projects in Education and Social Sciences (2nd ed.). Nairobi: Kanezja HP Enterprises.

Orodho, J. (2002). Research Method. Nairobi: Kenyatta University, Institute of Open Learning.

Orodho, J. (2009). Elements of Education Social Science Research Methods. KANEZJA Publisher, Maseno- Kenya.

Republic of Kenya (2017). Education for Sustainable Development for the Education Sector. UNON Publishing Services, Nairobi. 
Sarantakos, S. (2013). Social Research (4th ed.). Palgrave Macmillan: USA. https://doi.org/10.1007/978-1-137-29247-6

UNESCO. (2005). Education for All: The Quality Imperative. UNESCO: Paris.

UNESCO. (2011). EFA Global Monitoring Report: The Hidden Crisis: Armed Conflict and Education. UNESCO: Paris.

UNICEF. (2012). Education \& Early Childhood Development (ECD). Issue Briefs, Indonesia: UNICEF.

Winkler, D., \& Lars, S. (2008). The Efficiency of Public Education in Uganda. The World Bank. Retrieved 26/9/2015 from www.day7UgandaEfficiencystudy.pdf 